\title{
BRPKM
}

Buletin Riset Psikologi dan Kesehatan Mental

http://e-journal.unair.ac.id/index.php/BRPKM

e-ISSN: 2776-1851

ARTIKEL PENELITIAN

\section{Hubungan Kelekatan Ibu dan Anak dengan Kemandirian Santri}

\author{
ZAHROTUL RIZKI \& RUDI CAHYONO* \\ Fakultas Psikologi Universitas Airlangga
}

\begin{abstract}
ABSTRAK
Kelekatan merupakan suatu kecenderungan dimana individu mencari dan berusaha mempertahankan kedekatan dengan orang terdekat. Kemandirian merupakan suatu kemampuan untuk berpikir dan bertindak tanpa adanya pengaruh dari orang lain. Ada pola keterkaitan antara kelekatan dengan kemandirian menjadi salah satu tujuan dalam penelitian ini untuk mengetahui hubungan kelekatan ibu dan anak dengan kemandirian santri di Kota Jombang. Partisipan dalam penelitian ini adalah santriwan dan santriwati berusia 12-14 tahun di pondok pesantren Kota Jombang. Hasil penelitian ditemukan bahwa ada hubungan signifikan antara kelekatan ibu dan anak dengan kemandirian santri di Kota Jombang.
\end{abstract}

Kata kunci: ibu, kelekatan, kemandirian, santri

\begin{abstract}
Attachment is a tendency where individuals seek and try to maintain closeness with the closest person. Independence is the ability to think and act without the influence of others. There is a pattern of linkage between attachment and independence which is one of the objectives in this study to determine whether the relationship between mother and child attachment and the independence of students in Jombang City has a relationship. The participants in this study were female students and female students, aged 12-14 years, and Islamic boarding schools in the city of Jombang. The results of the study found that there was a significant relationship between mother and child attachment and the independence of students in the city of Jombang.
\end{abstract}

Keywords: attachment, independence, mother, students

Buletin Penelitian Psikologi dan Kesehatan Mental (BRPKM), 2021, Vol. 1(2), 1451-1456

*Alamat korespondensi: Fakultas Psikologi Universitas Airlangga, Kampus B Universitas Airlangga Jalan

Airlangga 4-6 Surabaya 60286.Surel: rudi.cahyono@psikologi.unair.ac.id

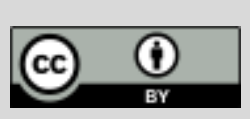

Naskah ini merupakan naskah dengan akses terbuka dibawah ketentuan the Creative Common Attribution License (CC-BY-4.0) (http://creativecommons.org/licenses/by/4.0), sehingga penggunaan, distribusi, reproduksi dalam media apapun atas artikel ini tidak dibatasi, selama sumber aslinya disitir dengan baik. 


\section{PEN D A H U L U A N}

Kabupaten Jombang memiliki motto kota yang beriman serta dikenal sebagai "Kota Santri". Penyebutan tersebut dikarenakan banyak pondok pesantren di Kota Jombang. Banyaknya pondok pesantren di Kota Jombang menjadi salah satu ciri khas bagi kota tersebut sehingga dikenal sebagai "Kota Santri". Pondok pesantren berguna untuk meningkatkan ilmu agama bagi anak. Umumnya, pondok pesantren berupa asrama yang menjadi tempat tinggal siswa dimana para siswa diharapkan mampu untuk menjadi disiplin pada dirinya sendiri Maharani (2017) .

Penyebutan siswa dalam pondok pesantren terbagi menjadi dua, yaitu santriwati dan santriwan. Ratarata usia pada santriwati dan santriwan termasuk golongan remaja. Dimana usia remaja memiliki rentang usia dari 13-18 tahun yang termasuk dalam jenjang SMP/MTS dan SMA/MA. Usia remaja memiliki transisi perkembangan yang terjadi antara masa kanak-kanak hingga masa dewasa serta melibatkan perubahan-perubahan baik secara biologis, kognitif, dan sosio-emosional (Steinberg \& Morris, 2001). Peran remaja adalah mampu untuk memaknai dan menjalani seluruh proses pencarian identitas dirinya dengan baik. Masalah umum yang terjadi pada remaja adalah pencarian identitas. Pencarian identitas ini digunakan untuk menemukan identitas dirinya melalui pengalaman dan pengetahuan yang selama ini dididik dengan orang tua atau guru sehingga remaja dapat menyatukan pengetahuan dan pengalamannya tersebut menjadi pembelajaran membentuk ciri khas masing-masing (Amin dkk., 2020).

Steinberg \& Morris (2001) mengatakan bahwa salah satu perkembangan anak untuk dapat mencapai tahapan selanjutnya adalah dengan menumbuhkan kemandirian. Kemandirian dalam remaja yaitu tidak bergantung pada orang lain serta dapat bertanggung jawab atas dirinya sendiri serta mampu menerima konsekuensi atas tindakan yang dilakukan (Steinberg \& Morris, 2001). Afiatin (1993) mengatakan bahwa terdapat tiga macam kemandirian. Pertama, kemandirian emosional, dimana kemandirian ini lebih cenderung pada keterikatan hubungan emosional remaja dengan orang lain. Selain itu, kemandirian emosional juga termasuk pada tidak bergantung pada bantuan dari orang tua sehingga remaja menjadi lebih mandiri. Kedua, kemandirian perilaku mengarah pada menentukan pilihan dan mengambil keputusan secara mandiri. Kemandirian ini juga menerima pendapat orang lain serta mampu mengambil keputusan secara tepat dan akurat. Ketiga, kemandirian nilai mengarah pada sikap independen dan keyakinan remaja pada spiritualitas, politik, serta moral (Suharnan, 2014).

Suharnan (2014) mengatakan bahwa kemandirian emosional menjadi dimensi kemandirian yang berhubungan dengan keterikatan remaja terhadap orang lain, salah satunya adalah pada orang tua. Salah satu cara kemandirian emosional ini terlihat pada saat individu hidup secara mandiri serta terpisah dari bantuan orang tua, maka mereka akan memulai hubungan baru dengan teman-teman di lingkungan pondok pesantren (Suharnan, 2014). Armsden dkk (1990) mengatakan bahwa faktor genetis ini berasal dari orang tua, pola asuh yang diterapkan oleh orang tua, sistem pendidikan di sekolah, serta individu berinteraksi dengan lingkungan di masyarakat. Faktor genetis menjadi banyak perdebatan, hal ini disebabkan karena individu menjadi lebih mandiri karena dibentuk melalui lingkungan, bukan pada sifat yang dibawa oleh orang tua mereka (Laursen \& Collins, 2009).

Namun, dalam proses pembentukan kemandirian, orang tua memiliki peran yang cukup besar salah satunya adalah ibu. Ibu menjadi lingkungan pertama serta menjadi sosok utama yang memiliki keterlibatan langsung dalam hal mengasuh anak sedari dini (Gillath dkk., 2008). Gillath dkk. (2008) mengatakan bahwa ada kaitan pola kelekatan kemandirian yang dilakukan orang tua, khususnya ibu dimana santri memiliki kapabilitas untuk melakukan kemandirian baik dengan lingkungan sekitar dan teman sebaya. 
Masum \& Wajdi (2018) mengatakan bahwa kemandirian dapat di lihat dari kelekatan anak dengan orang tuanya, pada awal tahun pertama landasan kehidupan yang penting bagi perkembangan psikologis anak adalah kemandirian. Kedekatan ibu dengan anak merupakan suatu fondasi yang penting dalam tumbuh kembang anak (Halushka, 1994). Apabila kelekatan tidak terjadi antara ibu dan anak atau justru kelekatan menjadi berlebihan akan memberikan dampak yang buruk bagi anak seperti anak menjadi lebih manja, selalu bergantung kepada orang tua, dan tidak mampu melakukan kemandirian sehingga tugas perkembangan anak akan terhambat (Halushka, 1994). Begitu, juga, kelekatan pada ibu dan anak tidak terjadi maka akan mempengaruhi kehidupan anak selanjutnya.

Suharnan (2014) menyatakan, kelekatan ibu dengan anak dinilai memiliki pengaruh yang positif pada perkembangan anak. Adanya interaksi selama di dalam kandungan, anak mampu berbicara, mendengar, merasakan, dan memaknai lingkungan sekitar melalui interaksi dengan orang tua. Mengindikasikan bahwa kelekatan ibu dan anak cukup penting dalam aspek kehidupan anak (Suharnan, 2014). Anak akan merasa ditinggalkan jika kelekatan dengan ibu berkurang, ini disebabkan karena anak membutuhkan sosok yang mampu melindungi dan membuat rasa aman (Gillath dkk., 2008).

Para santri diharapkan mampu menjadi mandiri dan bertanggung jawab atas dirinya sendiri. Namun, para santri yang masih tergolong remaja ini masih tergolong labil dan moody. Kemandirian merupakan salah satu tugas perkembangan anak, jika individu tidak mampu menyelesaikan tugas ini, maka anak akan cenderung lebih bergantung pada orang lain. Pola kemandirian ada keterkaitan dengan kelekatan dengan orang tua khususnya Ibu, dimana kemandirian dapat dilihat dengan kelekatan individu dengan orang tua. Oleh sebab itu, penulis bertujuan mengkaji lebih dalam mengenai hubungan kelekatan ibu dan anak terhadap kemandirian santri di Kota Jombang. Penulis ingin mengetahui ada atau tidaknya hubungan tersebut.

\section{MET ODE}

\section{Desain Penelitian}

Pengumpulan data pada penelitian menggunakan angket dimana penulis menyebarkan angket kepada santri di Kota Jombang. Pendekatan pada penelitian adalah korelasi, dimana penulis ingin menguji ada tidaknya hubungan kelekatan ibu dan anak terhadap kemandirian santri di Kota Jombang sehingga penelitian ini tergolong dalam penelitian kuantitatif.

\section{Partisipan}

Ada empat Pondok Pesantren besar yang ada di Kota Jombang menjadi alasan penulis dalam memilih partisipan, yaitu santriwan dan santriwati, berusia 12-14 tahun, dan tinggal di Pondok Pesantren di Kota Jombang (Pondok Pesantren Darul Ulum Peterongan, Pondok Pesantren Mamba'ul Ma'arif Denanyar, Pondok Pesantren Tebuireng, dan Pondok Pesantren Bahrul Ulum Tambak Beras). Penelitian ini melibatkan 222 partisipan.

\section{Pengukuran}

Pengukuran kelekatan diadaptasi dari skala kelekatan Maharani (2017) berdasarkan skala kelekatan yang diukur menggunakan yang dibuat oleh Armsden \& Greenberg (1987) yang terdiri dari 19 aitem, skala alat ukur likert yang terdiri dari dari 4 jawaban, yaitu 1= sangat tidak sesuai sampai dengan 4= sangat sesuai serta mencakup favorable dan unfavorable. Sedangkan, pengukuran kemandirian diadaptasi dari skala kemandirian Ulpa \& Zahara (2020) yang terdiri dari 40 aitem, skala alat ukur likert 
yang terdiri dari dari 4 jawaban yaitu, 1= Sangat Tidak Sesuai sampai dengan 4= Sangat Sesuai serta mencakup favorable dan unfavorable.

\section{Analisa Data}

Uji Product Moment digunakan untuk melihat hubungan kelekatan dan kemandirian. Dalam hal ini proses analisis data akan dilakukan dengan menggunakan bantuan perangkat lunak IBM SPSS StatisticS Version 22 for Windows dan Microsoft Excel. Uji validitas digunakan pada uji validitas variabel kelekatan pada penelitian sebelumnya oleh Armsden \& Greenberg (1987). Uji validitas menggunakan korelasi butir diperoleh nilai korelasi butir berkisar antara 0,388 hingga 0,316 maka validitas pada variabel kelekatan cukup valid dan sesuai apa yang akan diukur. Pada variabel kemandirian pada penelitian sebelumnya dilakukan oleh Suharnan (2014) uji validitas menggunakan korelasi butir diperoleh nilai korelasi butir sebesar 0,312 hingga 0,604, maka validitas pada variabel kemandirian cukup valid dan sesuai apa yang akan diukur. Uji validitas ini dibantu SPSS versi 22 for Windows. Uji reliabilitas pada alat ukur kelekatan memiliki nilai koefisien sebesar 0,890, sedangkan pada alat ukur kemandirian memiliki nilai koefisien sebesar 0,811.

\section{HAS I L P E N EL I T I A N}

Analisis statistik deskriptif diketahui pada variabel kelekatan nilai mean sebesar 59 (SD=5,19; Min=35; $M a x=76)$ artinya, kelekatan ibu dan anak pada penelitian ini memiliki kelekatan yang sedang. Pada variabel kemandirian diketahui bahwa pada nilai mean sebesar 127 (SD=12,4; Min=87; Max=160) artinya kemandirian santri di Kota Jombang memiliki kemandirian pada kategori yang tinggi. Hasil analisis korelasi, berdasarkan hasil analisis data menggunakan uji korelasi product moment $(r=0,348$; $p=0,000<0,001$ ) dimana hal ini menunjukkan bahwa terdapat hubungan positif secara signifikan antara kelekatan ibu dan anak dengan kemandirian santri di Kota Jombang. Adanya hubungan dua variabel ini mengindikasikan bahwa semakin tinggi kelekatan ibu dan anak maka semakin tinggi pula kemandirian santri. Sebaliknya, semakin rendah kelekatan ibu dan anak maka kemandirian pada santri juga akan semakin rendah. Sejalan dengan hal tersebut, berdasarkan hasil analisis data menunjukkan bahwa nilai $\left(R^{2}\right)$ sebesar 0,121, dimana hal ini menunjukkan bahwa kelekatan ibu dan anak memberikan sumbangan efektif sebesar $12,1 \%$ pada kemandirian santri, sedangkan sisanya dipengaruhi oleh faktorfaktor diluar penelitian ini yang dapat mempengaruhi kelekatan ibu dan anak terhadap kemandirian santri di daerah Jombang.

\section{I S K U S I}

Berdasarkan hasil uji product moment pearson correlation ditemukan bahwa ada hubungan kelekatan ibu dan anak dengan kemandirian pada santri di Kabupaten Jombang, dimana ada hubungan yang secara positif dan signifikan antara kelekatan ibu dan anak dengan kemandirian santri di Kabupaten Jombang. Ada hubungan yang positif ini menunjukkan bahwa jika kelekatan ibu dan anak tinggi maka semakin tinggi pula kemandirian santri, sebaliknya semakin rendah kelekatan ibu dan anak maka kemandirian pada santri juga akan semakin rendah. Steinberg \& Morris 2001) mengatakan bahwa anak yang tumbuh dengan kelekatan yang aman bersama orang tuanya akan lebih cenderung memiliki rasa harga diri yang tinggi, kebahagiaan, dan kesejahteraan emosi. Adanya konflik sehari-hari berupa perselisihan kecil antar keluarga menjadi sebuah fasilitas bahwa remaja menjadi lebih mandiri dan tidak bergantung pada orang tua maupun orang lain. Amin dkk (2020) juga menjelaskan peran ibu sangat besar dalam pola keluarga, sebagai pendukung, membantu suami, serta mengurus anak. Armsden \& Greenberg (1987)

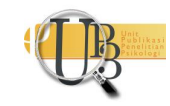


menjelaskan bahwa kelekatan terhadap ibu dan ayah menjadi salah satu faktor utama dalam terbentuknya kemandirian anak.

Masum \& Wajdi (2018) mengatakan bahwa kelekatan tahap awal pada saat periode bayi, jika ibu tidak mampu memberikan kelekatan saat periode ini maka akan mempengaruhi kepribadian anak, kemampuan sosial, serta keamanan bagi anak. Kelekatan ibu dan anak menjadi salah satu dasar pentingnya perkembangan serta kemandirian pada si anak. Salah satu anak menjadi mandiri adalah ketika ibu dan anak tidak terlalu terlekat dan tidak terlekat secara berlebihan sehingga anak mampu menjadi lebih mandiri dan tanpa bantuan orang lain. Berdasarkan uji beda, pada kemandirian santriwan dan santriwati di Kota Jombang tidak mengalami perbedaan secara signifikan. Hal ini berbeda dari penelitian sebelumnya milik Amin dkk (2020) dimana penelitian terhadap 400 partisipan yang berada pada rentang usia 12-18 tahun, ditemukan bahwa pada remaja laki-laki lebih besar tingkat kemandirian dibandingkan santriwati. Maharani (2017) juga menemukan bahwa ada perbedaan secara signifikan antara santriwan dan santriwati pada kemandirian, dimana pada santriwan lebih banyak diberikan kesempatan dalam mandiri serta menanggung banyak risiko dibandingkan santriwan juga lebih dituntut lebih inisiatif dibandingkan santriwati.

\section{S I M P U L A N}

Hasil ditemukan ada hubungan antara kelekatan ibu dan anak dengan kemandirian santri di Kota Jombang. Pada arah korelasi menunjukkan arah korelasi yang positif ini berarti semakin tinggi kelekatan ibu dan anak, maka semakin tinggi tingkat kemandirian santri pada Kota Jombang, begitupun sebaliknya. Saran penelitian yaitu yang pertama saran untuk subjek, remaja diharapkan dapat memahami pentingnya kemandirian dan dapat mengambil nilai-nilai yang positif misalnya tidak menggantungkan diri pada orang lain, bertanggung jawab dan dapat menempatkan diri sebagai mana mestinya sehingga mudah melakukan otonomi diri di mana pun mereka berada. Kemudian saran yang kedua untuk pondok pesantren, pihak pondok diharapkan untuk menggabungkan model pendidikan agama dan aspek-aspek kemandirian yang diaplikasikan di dalam aktivitas pondok sehingga seluruh santri mampu belajar mandiri di lingkungan sekolah atau di lingkungan pondok pesantren. Terakhir, saran untuk penelitian selanjutnya, untuk peneliti selanjutnya diminta agar makin memperluas pondok pesantren yang ada di Kota Jombang supaya hasil yang didapatkan lebih optimal. Peneliti selanjutnya pun mampu memakai variabel lain yang bisa dikaitkan kemandirian atau variabel lain yang dapat dipengaruhi oleh kelekatan.

\section{U C A P A N T E R I MAKASIH}

Penulis mengucapkan terima kasih kepada pihak-pihak yang mendukung saya. Dosen pembimbing saya, Pak Rudi Cahyono yang membimbing penulis hingga mampu menyelesaikan skripsi sampai tuntas serta keluarga yang tak henti-hentinya memberikan dukung dan doa kepada penulis.

\section{DEKLARASI POTENSI TERJADINYA KONFLIK KEPENTINGAN}

Zahrotul Riski dan Rudi Cahyono tidak bekerja, menjadi konsultan, memiliki saham, atau menerima dana dari perusahaan atau organisasi manapun yang mungkin akan mengambil untung dari diterbitkannya naskah ini. 


\section{PUST AKA ACUAN}

Afiatin, T. (1993). Persepsi pria dan wanita terhadap kemandirian. Jurnal Psikologi, 20(1).

Amin, M., Kristiana, D., \& Fadlillah, M. (2020). Pengaruh kelekatan aman anak pada ibu terhadap kemandirian anak usia 5-6 tahun. Jurnal Obsesi: Jurnal Pendidikan Anak Usia Dini, 5(1), 127. https://doi.org/10.31004/obsesi.v5i1.504

Armsden, G. C., \& Greenberg, M. T. (1987). The inventory of parent and peer attachment: Individual differences and their relationship to psychological well-being in adolescence. Journal of Youth and Adolescence, 16(5), 427-454. https://doi.org/10.1007/BF02202939

Armsden, G. C., McCauley, E., Greenberg, M. T., Burke, P. M., \& Mitchell, J. R. (1990). Parent and peer attachment in early adolescent depression. Journal of Abnormal Child Psychology, 18(6), 683-697. https://doi.org/10.1007/BF01342754

Gillath, O., Shaver, P. R., Baek, J.-M., \& Chun, D. S. (2008). Genetic correlates of adult attachment style. Personality and Social Psychology Bulletin, 34(10), 1396-1405. https://doi.org/10.1177/0146167208321484

Halushka, P. V. (1994). A message from the scientific program committee chairperson: Submission of abstracts for the 1995 annual meeting. Clinical Pharmacology and Therapeutics, 55(6), 702-702. https://doi.org/10.1038/clpt.1994.88

Laursen, B., \& Collins, W. A. (2009). Parent-child relationships during adolescence. In R. M. Lerner \& L. Steinberg (Eds.), Handbook of Adolescent Psychology. John Wiley \& Sons, Inc. https://doi.org/10.1002/9780470479193.adlpsy002002

Maharani, R. (2017). Hubungan antara kelekatan pada orang tua dengan kesejahteraan psikologis remaja [Skripsi, Universitas Muhammadiyah Malang]. http://eprints.umm.ac.id/44056/

Masum, T., \& Wajdi, M. B. N. (2018). Pengembangan kemandirian pesantren melalui program santripreneur. Engagement: Jurnal Pengabdian Kepada Masyarakat, 2(2), 221-232. https://doi.org/10.29062/engagement.v2i2.40

Steinberg, L., \& Morris, A. S. (2001). Adolescent development. Annual Review of Psychology, 52(1), 83110. https://doi.org/10.1146/annurev.psych.52.1.83

Suharnan. (2014). Pengembangan skala kemandirian. Persona:Jurnal Psikologi Indonesia, 1(2). https://doi.org/10.30996/persona.v1i2.26

Ulpa, E. P., \& Zahara, N. (2020). Hubungan Kemandirian dengan Penyesuaian Diri pada Santri Pondok Pesantren Diniyyah Putri Lampung. ANFUSINA: Journal of Psychology, 3(1), 109-118.

https://doi.org/10.24042/ajp.v3i1.6142 